University of Nebraska - Lincoln

DigitalCommons@University of Nebraska - Lincoln

\title{
Winter Cover Crops and Vinegar for Early-Season Weed Control in Sustainable Cotton
}

\author{
P. J. Moran \\ USDA-Agricultural Research Service, Patrick.Moran@ars.usda.gov
}

S. M. Greenberg

USDA-Agricultural Research Service, Shoil.Greenberg@ars.usda.gov

Follow this and additional works at: https://digitalcommons.unl.edu/usdaarsfacpub

Part of the Agricultural Science Commons

Moran, P. J. and Greenberg, S. M., "Winter Cover Crops and Vinegar for Early-Season Weed Control in Sustainable Cotton" (2008). Publications from USDA-ARS / UNL Faculty. 575.

https://digitalcommons.unl.edu/usdaarsfacpub/575

This Article is brought to you for free and open access by the U.S. Department of Agriculture: Agricultural Research Service, Lincoln, Nebraska at DigitalCommons@University of Nebraska - Lincoln. It has been accepted for inclusion in Publications from USDA-ARS / UNL Faculty by an authorized administrator of DigitalCommons@University of Nebraska - Lincoln. 


\title{
Winter Cover Crops and Vinegar for Early-Season Weed Control in Sustainable Cotton
}

\author{
P. J. Moran \\ S. M. Greenberg
}

\begin{abstract}
Weeds may be suppressed by winter cover crops and the use of organic herbicides such as vinegar. Black oat (Avena strigosa) and hairy vetch (Vicia villosa) winter cover crops were planted for 2 years as part of a sustainable production system for cotton in the Lower Rio Grande Valley of Texas, and were till-killed each spring prior to cotton planting. Palmer amaranth (Amaranthus palmeri), common purslane (Portulaca oleracea), and sunflower (Helianthus annuиs) were frequently-encountered winter and spring weeds. Both cover crops controlled winter weeds as well as did winter tillage without cover. Black oats plots had $8 \%$ and $17 \%$ more total winter weed cover than no-cover and hairy vetch plots, respectively. Seven weeks after cotton planting, cotton cover was $10 \%$ to $15 \%$ less in former winter hairy vetch and no-cover sustainable plots than in former black oats plots, but cotton height did not vary by winter cover crop. Total spring weed, pigweed, and purslane cover did not vary between former hairy vetch, black oats, and no-cover plots. All sustainable plots had higher spring weed cover than did conventional plots maintained with cultivation and synthetic herbicides. Breakdowns in the sustainable spring weed management system (withholding of spring cultivation) or insect pest
\end{abstract}

P. J. Moran and S. M. Greenberg are affiliated with the USDA-Agricultural Research Service, Beneficial Insects Research Unit, 2413 E. Hwy 83, Weslaco, TX 78596 (E-mail: Patrick.Moran@ars.usda.gov; Shoil.Greenberg@ars.usda.gov).

Mention of trade names or commercial products in this article is solely for the purpose of providing specific information and does not imply recommendation or endorsement by the U.S. Department of Agriculture.

Address correspondence to: P. J. Moran at the above address.

Journal of Sustainable Agriculture, Vol. 32(3) 2008

Available online at http://www.haworthpress.com

(c) 2008 by The Haworth Press. All rights reserved. doi:10.1080/10440040802257835 
management system (failure of alfalfa strips) led to increases of $60 \%$ or more in weed cover in sustainable plots. Cotton lint yield ( $\mathrm{kg} / \mathrm{ha})$ did not differ between sustainable and conventional weed management systems. When evaluated as a cover crop and weed management tool, vinegar containing $9 \%$ acid $(1,550 \mathrm{~L} / \mathrm{ha})$ reduced live hairy vetch cover to less than $5 \%$ in one of two trials, but was not effective as a burndown herbicide on black oats. Vinegar at this concentration $(2,980 \mathrm{~L} / \mathrm{ha})$ killed $>80 \%$ of 30 -day-old or younger cotton and sunflower and 10-day-old Palmer amaranth and purslane in field trials, but caused $<50 \%$ mortality to mature Palmer amaranth and purslane. More dilute vinegar solutions $(0.9 \%$ to $4.5 \%$ acid $)$ caused little or no mortality. Black oats and hairy vetch covers controlled winter but not spring weeds in this production system. With more prolonged use, winter covers could become a key spring weed control component in sustainable cotton production. Vinegar could be useful in controlling young weed seedlings in non-crop areas, or as a follow-up to cultivation.

KEYWORDS. Acetic acid, black oats, cotton, hairy vetch, pigweed, purslane, Rio Grande Valley, sunflower, Texas, weed cover

\section{INTRODUCTION}

Sustainable agriculture encompasses a wide range of physical, cultural, biological, and chemical weed control techniques and seeks to minimize offfarm inputs in all phases of crop production (Labrada, 2006; Mohler, 2001a). Organic crop production specifically excludes synthetic inputs (Kuepper, 2002). In cotton, weeds are an important obstacle to production, and can reduce yield in the absence of control (Griffith et al., 2006; Rowland et al., 1999; Showler and Greenberg, 2003), usually requiring the use of synthetic herbicides (Burgos et al., 2006). Only $0.03 \%$ of total U.S. cotton acreage was grown organically in 2001, but consumer demand for organic cotton products is growing (Guerena and Sullivan, 2003). In the subtropical Lower Rio Grande Valley (LRGV) of Texas, over 200,000 acres of cotton are planted annually (Norman, 2004). Weeds grow and produce seed year-round in the absence of control. Information on sustainable weed control in cotton, as a component of multiple pest, fertilizer, and crop growth management systems, is limited in this region and nationally (Liebman, 2001).

Many crop production techniques are compatible with sustainable and organic weed control, including various tillage regimes (Mohler, 2001b), inter-row cultivation, mulching, weed flaming, the coating of seed with deleterious rhizobacteria (Kremer, 2002), the application of plant pathogenic 
fungi as bioherbicides (Ortiz-Ribbing and Williams, 2006), crop rotation, and cover cropping (Guerena and Sullivan, 2003). For example, alfalfa strips support beneficial predators and parasites of insect pests (DeBach, 1964; Ellington et al., 2003; Guerena and Sullivan, 2003) but may also affect weed populations. Winter cover crops, including black oats (Avena strigosa Schreb.) and hairy vetch (Vicia villosa Roth) suppress weeds via chemical allelopathy (Batish et al., 2006; Hill et al., 2006; Nava-Rodriguez et al., 2005), physical blockage and shading (Teasdale and Mohler, 2000) and by increasing seed predator abundance (Clark et al., 2006). Leguminous covers such as hairy vetch increase plant-accessible soil nitrogen (Sainju et al., 2005). Cover crops also improve soil composition; conserve soil carbon, nitrogen, and moisture content; and enhance microbial activity (Hoffman and Regnier 2006; Yenish et al. 1996), leading to increases in the growth and yield of cotton (Bauer and Reeves, 1999; Sainju et al., 2005) and other crops (Burgos et al., 2006; Fisk et al., 2001; Nagabhushana et al., 2001). Questions remain about the benefits of live versus killed covers in no-till crop production (Teasdale and Daughtry, 1993) and the importance of soil incorporation of residue (Mohler, 2001b; Schomberg et al., 2006). This study examined the effects of black oat and hairy vetch winter covers on winter and spring weeds in the LRGV of Texas, in the context of a sustainable weed, pest, and soil management system for cotton.

A limited number of chemical substances, including vinegar (Garrett and Beck, 1999, Webber et al., 2005) have been approved for specific uses in organic production under the USDA National Organic Program (Kuepper, 2002, OMRI, 2007). Vinegar has herbicidal effects on broadleaf and grass weeds (Fausey, 2003; Spencer et al., 2003; Webber et al., 2005; Young, 2004), and the high acetic acid content of immature mulches contributes to weed control (Ozores-Hampton et al., 2002). In the absence of synthetic herbicides, vinegar applications could kill cover crops before crop production begins, and reduce the need for frequent cultivation and hand-weeding during production. The effects of vinegar on hairy vetch, black oats, and several abundant broadleaf weeds were therefore evaluated.

\section{MATERIALS AND METHODS}

\section{Cover Crops and Sustainable Cotton Production}

Winter cover crop and sustainable early-season cotton production involved a 2 ha field of Hidalgo fine sandy loam (fine-loamy mixed, 
hyperthermic Typic Calciustolls, $543 \mathrm{~g} / \mathrm{kg}$ sand, $205 \mathrm{~g} / \mathrm{kg}$ silt, $252 \mathrm{~g} / \mathrm{kg}$ clay, pH 7.9, organic C $10.3 \mathrm{~g} / \mathrm{kg}$, organic N $0.95 \mathrm{~g} / \mathrm{kg}, \mathrm{P} 6.4 \mathrm{mg} / \mathrm{kg}$, $\mathrm{K} 25.4 \mathrm{mg} / \mathrm{kg}$ ) (Zibilske and Bradford, 2003) divided into 0.2 ha (0.5 acre) plots, $20 \mathrm{~m}(66 \mathrm{ft})$ wide by $100 \mathrm{~m}(328 \mathrm{ft})$ long, located at the USDAARS, Kika de la Garza Subtropical Agricultural Research Center (KSARC) in Hidalgo County, Texas, USA (26 $\left.16^{\prime} \mathrm{N}, 9^{\circ} 59^{\prime} \mathrm{W}\right)$. In October 2004 and 2005, the field was plowed, disked, and bedded on $0.8 \mathrm{~m}$ $(2.6 \mathrm{ft})$ centers. Cover crop experiments used a randomized complete block design with three replications. On 9 November 2004 and 15 December 2005, cover crops were planted in 18 rows per plot using a UFT grain drill (United Farm Tools, South Charleston, WV) with six rows left unseeded in each plot as a turn row. Seeding rates were $50.4 \mathrm{~kg} / \mathrm{ha}$ (45 lb/acre) for black oats (Avena strigosa, cv. Soilsaver) (BO) and $28 \mathrm{~kg} / \mathrm{ha}$ (25 lb/acre) for hairy vetch (Vicia villosa) (HV). One plot per block was designated as a no-cover plot (NC). Before planting, BO and $\mathrm{HV}$ plots received $201 \mathrm{~kg} / \mathrm{ha}$ (179 lb/acre) granular sulfur and NC plots received 1120 $\mathrm{kg} / \mathrm{ha}$ (1000 lb/acre) poultry litter, incorporated with a six-row Lilliston cultivator (Bigham Brothers, Lubbock, TX). All plots were irrigated at the time of planting and $3 \mathrm{wk}$ after planting (WAP). Total precipitation from November 2004 through February 2005 was $7.4 \mathrm{~cm}$ (2.9 in), and from November 2005 to February 2006 it was $5.4 \mathrm{~cm}$ (2.1 in); the 30-year normal for this period at this location is $17.2 \mathrm{~cm}(6.8 \mathrm{in}) . \mathrm{NC}$ plots were tilled 4 wk after planting.

Seven WAP covers, all plots were tilled, killing the cover crops. In 2005 only, sorghum (Sorghum vulgare L.) was planted in six buffer rows between plots at a rate of 400,000 seeds/ha (162,000 seeds/acre) using a Max-Emerge ${ }^{\circledR}$ planter (John Deere, Moline, IL). In 2005 and 2006, six rows of alfalfa (Medicago sativa L.) were hand-seeded (28 kg/ha, $25 \mathrm{lb} / \mathrm{acre}$ ) into $\mathrm{HV}$ and $\mathrm{BO}$ plots as a green manure, with two rows on each inner edge of the plots and two rows in the center, placed between six planned cotton rows. Alfalfa seed was incorporated with a two-row Lilliston cultivator. Cotton (Gossypium hirsutum L., variety Fiber Max 960RR, non-Bt, glyphosate-tolerant) (Bayer Crop Science, Research Triangle Park, NC) was planted on 7 March 2005 and 20 March 2006 at a rate of 124,000 seeds/ha $(50,200$ seeds/acre) to a soil depth of 2 to $3 \mathrm{~cm}(0.75$ to $1.2 \mathrm{in})$, in 12 rows in $\mathrm{HV}$ and $\mathrm{BO}$ plots and 18 rows in NC plots. Seedlings emerged within $1 \mathrm{wk}$. All sustainable plots were furrow-irrigated 2 and 6 WAP, and the soil between rows was sweep-cultivated 4 WAP. Compost tea was added 3.5 WAP cotton to promote positive soil-microbial-plant interactions (Carpenter-Boggs, 2005) and improve pest resistance 
(Litterick et al., 2004). Compost tea was brewed in a Worm-Gold ${ }^{\circledR}$ Extractor (California Vermiculture, Cardiff-by-the-Sea, CA), according to the manufacturer's instructions and Ingham (2005), from $3.0 \mathrm{~g} / \mathrm{L}$ $(0.4 \mathrm{oz} /$ gallon $)$ bat guano, $6.0 \mathrm{~g} / \mathrm{L}(0.8 \mathrm{oz} / \mathrm{gallon})$ worm castings, $3.0 \mathrm{~g} / \mathrm{L}$ ( $0.4 \mathrm{oz} / \mathrm{gallon})$ standard compost, $1.2 \mathrm{~g} / \mathrm{L}(0.16 \mathrm{oz} / \mathrm{gallon}) \mathrm{kelp}$ meal, and $2.6 \mathrm{ml} / \mathrm{L}$ ( 0.3 fluid oz/gallon) each of humic acid and molasses, and was applied using a tractor-mounted sprayer with Lurmark DT20 (Hypro Inc., New Brighton, MN) horizontal fan spray tips calibrated to deliver $187 \mathrm{~L} / \mathrm{ha}$ (20 gallon/acre) at $345 \mathrm{kPa}(50 \mathrm{psi})$ moving at $0.9 \mathrm{~m} / \mathrm{sec}(2 \mathrm{miles} / \mathrm{hr})$. In the first $7 \mathrm{WAP}$, azadirachtin (72 g ai/ha or $1.0 \mathrm{oz}$ ai/acre) $\left(\mathrm{Neemix}^{\circledR}\right.$, Certis USA, Columbia, MD), rosemary oil (210 $\mathrm{ml}$ ai/ha or $2.87 \mathrm{fl} \mathrm{oz} \mathrm{ai/acre)}$ (Sporan ${ }^{\circledR}$, Ecosmart Technologies, Franklin, TN), and spinosad (66 g ai/ha or $0.94 \mathrm{oz} \mathrm{ai} / \mathrm{acre})\left(\right.$ Spintor $^{\circledR}$, Dow Agrosciences, Indianapolis, IN) were applied to control insect pests using the same equipment. Rainfall in March-April 2005 was $1.1 \mathrm{~cm}(0.5 \mathrm{in})$ and in the same period in 2006 it was $1.8 \mathrm{~cm}(0.7 \mathrm{in})$. Normal (30-year) precipitation for this period at this location is $5.2 \mathrm{~cm}$ ( $2.0 \mathrm{in})$.

In 0.2 ha $(0.5$ acre) plots in separate fields, cotton (variety DP 541 BGII/RR, glyphosate-tolerant and Bt-transgenic) (Monsanto, St. Louis, MO) was cultivated using conventional chemical tools. Pre- and postplanting tillage, planting date, cotton seeding rate and irrigation in these plots were similar to sustainable plots. Synthetic fertilizer $(22.4 \mathrm{~kg} / \mathrm{ha}$ or $19.9 \mathrm{lb} / \mathrm{acre} \mathrm{N}, 56 \mathrm{~kg} / \mathrm{ha}$ (50 lb/acre) P, no potassium), glyphosate (0.95 $\mathrm{kg}$ ai/ha or $0.85 \mathrm{lb}$ ai/acre) (RoundUp ${ }^{\circledR}$, Monsanto, St. Louis, MO) and dicamba methylamine salt $(1.13 \mathrm{~kg}$ ai/ha or $1 \mathrm{lb}$ ai/acre $)\left(\right.$ Banvel $^{\circledR}$, Micro Flo LLC, Memphis, TN) were applied to conventional fields before cotton planting. Insects were controlled with acephate $(75.6 \mathrm{~g}$ ai/ha or $1.1 \mathrm{oz}$ ai/acre $)$ (Orthene $90 \mathrm{~S}^{\circledR}$, Valent Co., Walnut Creek, CA) and oxamyl $(1.0 \mathrm{~kg}$ ai/ha or $0.89 \mathrm{lb}$ ai/acre) (Vydate $\mathrm{CLV}^{\circledR}$, Dupont Inc., Wilmington, DE) within the first 7 WAP. Liquid applications used an 18-row sprayer (John Deere 6500) with Teejet 8002 vertical fan nozzles (Teejet Mid Tech, Wheaton, IL) and a Raven SCS440 control system.

\section{Winter and Spring Weed Sampling}

Winter weeds in sustainable cotton plots were sampled 6 WAP cover crops (20 December 2004, 31 January 2006) in one linear transect per plot using five $1 \mathrm{~m}^{2}\left(10.76 \mathrm{ft}^{2}\right)$ subplots spaced $20 \mathrm{~m}(66 \mathrm{ft})$ apart in 2005, and in eight subplots per transect in 2006. Hairy vetch plants were mature and flowering at the time of sampling (mean $\pm \mathrm{SE} ; 55 \pm 4 \mathrm{~cm}$ breadth of 
prostrate stems per plant, $16 \pm 1$ shoots $/ \mathrm{m}^{2}$ ), while black oat plants were pre-reproductive $\left(32.8 \pm 7.5 \mathrm{~cm}\right.$ height, $82.3 \pm 4.5$ shoots $\left./ \mathrm{m}^{2}\right)$. Based on shoot counts and visual coverage estimates, each hairy vetch stem occupied $0.02 \mathrm{~m}^{2}$ area, and each black oat shoot occupied $0.0089 \mathrm{~m}^{2}$. Spring weeds were sampled 7 WAP cotton (29 April 2005, 10 May 2006) in the nine sustainable plots and in three conventional plots. Cotton plants were approximately $23 \mathrm{~cm}$ (9 in) tall and had 8 to 10 nodes at the time of sampling. Spring weeds and cotton were also sampled in each of three conventional cotton plots using one transect containing five subplots. Within the sustainable field, one additional spring transect was sampled in each of six alfalfa strips that were planted without cotton in the middle of the BO and HV plots (five subplots per transect in 2005, three in 2006). In the spring of 2006 , one small strip $(5 \mathrm{~m}$ long $\times 1 \mathrm{~m}$ wide, or $16.4 \mathrm{ft} \times 3.3 \mathrm{ft}$ ) within eight of the nine sustainable cotton plots was left uncultivated when the rest of the plots were cultivated 4 WAP. Three $1 \mathrm{~m}^{2}$ subplots were sampled within each of these strips 7 WAP.

In 2005 and 2006 winter and spring subplots, total percent plant cover, cover crop or cotton cover, and Palmer amaranth (Amaranthus palmeri Wats.) and common purslane (Portulaca oleracea L.) cover were visually estimated. Total weed cover was calculated by subtracting cover crop or cotton cover from total plant cover. In spring subplots, the proportions of total percent plant cover consisting of weeds, cotton, Palmer amaranth and purslane were determined. In 2006 subplots only, the presence or absence and cover occupied by all broadleaf weeds and sedges that could be identified with Richardson (1995), and unidentified grasses (winter subplots) or identified common grasses (spring subplots) were also determined. Numbers of Palmer amaranth and purslane shoots were determined in winter 2005 subplots. The number of Palmer amaranth shoots was determined in spring 2006 subplots. In spring subplots in cotton rows, the shoot heights of two cotton plants per subplot were measured and averaged.

Winter 2005 and 2006 data were combined because there were no significant differences between years in preliminary analyses. In spring sampling, total weed cover in the sustainable plots was significantly higher in 2006 (18\% to $29 \%)$ than in $2005(2-9 \%)(\mathrm{F}=73.9$, df $=1,2, \mathrm{p}<0.05)$. Only data from 2006 are presented. Differences in the frequency of occurrence (presence/absence) of weed species were examined with likelihoodratio Chi-square tests (SAS Institute, 1999). Cover estimates were acrsine-square root transformed. Shoot counts of Palmer amaranth and purslane were $\log (\mathrm{x}+1)$ transformed. Means derived from untransformed 
data $( \pm \mathrm{SE})$ are presented. All winter and spring cover estimates, weed shoot count and cotton height data from the sustainable field were analyzed with SAS PROC MIXED (SAS Institute, 1999) with cover crop as the fixed effect and block, subplot nested within block, and the blockcover crop interaction as random effects. Differences among cover crops were examined via least-squares means, t-tests, and Tukey-Kramer adjusted $\mathrm{p}$ values. A similar approach was used to compare uncultivated strips to cultivated areas within sustainable plots in spring 2006 samples, but in this case winter cover crop, cultivation and their interaction were included as fixed effects. Follow-up tests examined the effects of withholding cultivation separately for each winter cover crop treatment. Differences between 2005 and 2006 in alfalfa and spring weed cover in the alfalfa strips were examined by combining data from $\mathrm{HV}$ and $\mathrm{BO}$ plots and specifying year as the only fixed effect.

\section{Cotton Yield Determination}

The effects of sustainable ( $\mathrm{HV}, \mathrm{BO}$, or $\mathrm{NC}$ treatments combined) and conventional weed control on cotton yield was assessed by hand-weeding the sustainable plots $8 \mathrm{WAP}$, cultivating all plots $9 \mathrm{WAP}$, continuing the insect control techniques noted above, applying mepiquat chloride (1.3 $\mathrm{g}$ ai/ha or $0.03 \mathrm{oz}$ ai/acre) (Mepichlor ${ }^{\circledR}$, Micro Flow LLC., Memphis, TN) to all plots 12 WAP to control cotton height, and applying ethephon (8.2 $\mathrm{g}$ ai/ha or $0.1 \mathrm{oz}$ ai/acre) (Prep ${ }^{\circledR}$, Bayer Crop Science) and thidiazuron (20.8 g ai/ha or 0.3 oz ai/acre) (Dropp ${ }^{\circledR}$ SC, Bayer Crop Science) defoliants to all plots $17 \mathrm{WAP}$. A prior application of organic defoliant $(163.7 \mathrm{~L} / \mathrm{ha}$ or 17.5 gallons/acre $20 \%$ vinegar and $11.7 \mathrm{~L} /$ ha or 1.3 gallons/acre each of orange oil and molasses) to the sustainable plots did not produce sufficient plant mortality. Seed cotton was hand-collected 18 WAP in 9 or 10 $4 \mathrm{~m}$ (14 ft) sampling rows each in the sustainable and conventional fields. Lint was separated with an Eagle laboratory gin (Continental Gin Co., Birmingham, AL) and weighed. The difference in yield between sustainable and conventional production systems was analyzed with a $t$-test.

\section{Vinegar Burndown Treatment of Cover Crops}

All vinegar studies used household distilled white vinegar (9\% acetic acid content) (HEB Inc., San Antonio, TX). All vinegar solutions were mixed with $1 \%(\mathrm{v} / \mathrm{v})$ surfactant (potassium salts of fatty acids) (Safer Soap ${ }^{\circledR}$ concentrate containing $49.5 \%$ ai, Woodstream Inc., Lititz, PA). This product has been approved for use in organic agriculture (OMRI, 
2005). All vinegar applications were made with a $3.8 \mathrm{~L}$ (1 gallon) handheld sprayer with a cone fan nozzle pressurized to $276 \mathrm{KPa}$ (40 psi) (Model 2751E, Chapin Inc., Batavia, NY). Applications were made between 0900 and 1100 in full sun, and in windspeeds $<5 \mathrm{~m} / \mathrm{sec}$ (10 mph). To test the ability of vinegar to kill cover crops, 9\%, $4.5 \%$, $0.9 \%$ vinegar solutions were applied $[1550 \mathrm{~L} / \mathrm{ha}$ (166 gallons/acre) solution, containing $138 \mathrm{~L}$ ai/ha (14.8 gallons ai/acre) for $9 \%, 69.1 \mathrm{~L}$ ai/ha $(7.4$ gallons ai/acre) for $4.5 \%, 13.8 \mathrm{~L}$ ai/ha (1.48 gallons ai/acre) for $0.9 \%$, or $15.5 \mathrm{~L}$ ai/ha (1.7 gallons ai/acre) surfactant for the $0 \%$ control solution] 7 WAP to $1-\mathrm{m}^{2}\left(10.76 \mathrm{ft}^{2}\right)$ subplots inside $\mathrm{HV}, \mathrm{BO}$, or NC plots (two subplots per vinegar concentration per plot, six total subplots per cover crop per vinegar concentration). In a separate field (Willacy fine sandy loam [fineloamy, mixed hyperthermic Udic Argiustolls]) an application to hairy vetch was performed 8 WAP covers (six subplots per vinegar concentration). Percent live cover crop coverage was visually estimated before and one week after vinegar application. The overall effect of vinegar on the change in live cover was analyzed using Kruskal-Wallis $\chi^{2}$ tests, and asymptotic Wilcoxon tests were used to determine differences between each vinegar concentration and the control solution (PROC NPAR1WAY) (SAS Institute, 1999).

\section{Vinegar Treatment to Control Weeds}

The effect of $9 \%$ vinegar or control solution on mortality of purslane shoots $\left(82 \pm 19\right.$ shoots $/ \mathrm{m}^{2}$ density before application, $7 \pm 1 \mathrm{~cm}$ breadth of prostrate stems on the ground, $21 \pm 2$ leaves, 25 plants measured) was examined in $1 \mathrm{~m}^{2}$ plots located on the edge of the sustainable cotton field, (six plots per treatment), using the same application rates and equipment as for cover crops. The effects of $0 \%, 0.9 \%, 4.5 \%$, or $9 \%$ vinegar on mortality of winter Palmer amaranth and sunflower (Helianthus annuus L.) were examined by spraying individual shoots $(30 \mathrm{~mL} /$ plant solution $[1 \mathrm{fl}$ oz/plant]) (10 plants per weed species per vinegar concentration) with the hand-held pressure sprayer. Palmer amaranth plants were mature and flowering (mean $\pm \mathrm{SE} ; 21 \pm 3 \mathrm{~cm}$ tall, $47 \pm 10$ leaves, 28 plants measured), while sunflower plants were pre-reproductive (16 $\pm 4 \mathrm{~cm}$ tall, $34 \pm 9$ leaves, 12 plants measured). In May 2006, individual common purslane, Palmer amaranth and sunflower shoots were sprayed with $9 \%$ vinegar [ $40 \mathrm{~mL}$ solution/plant (1.4 fl oz/plant)] (26 to 27 plants per weed species; no control treatment). Palmer amaranth plants were mature and flowering $(29 \pm 3 \mathrm{~cm}$ tall, $63 \pm 16$ leaves) as were purslane plants $(38 \pm 4 \mathrm{~cm}$ 
breadth of prostrate stems), while sunflower plants were pre-reproductive (20 $\pm 3 \mathrm{~cm}$ tall, $22 \pm 4$ leaves). Shoot mortality was determined 1 week after application.

In a field experiment in August 2005, the effects of 9\%, 4.5\%, 0.9\%, and $0 \%$ vinegar on mortality of young, vegetative Palmer amaranth shoots ( $8 \pm 0.2 \mathrm{~cm}$ tall, $13 \pm 0.4$ leaves) and mature, flowering shoots (42 $\pm 2 \mathrm{~cm}$ tall, $40 \pm 2$ leaves) were examined in $1 \mathrm{~m}^{2}$ plots in fallow fields adjacent to the sustainable cotton field. Young volunteer cotton $(9 \pm 0.3 \mathrm{~cm}$ tall, $3 \pm 0.2$ leaves) was also present in the plots containing young Palmer amaranth. Vinegar was applied with the hand-held pressure sprayer to five plots per vinegar concentration per Palmer amaranth age, delivering $900 \mathrm{ml}(30.4 \mathrm{fl} \mathrm{oz}$ ) solution to each mature plot (for 9\%, 4.5\%, and $0.9 \%$ vinegar solutions, this volume equals 801,405 , and $81 \mathrm{~L}$ ai/ha, or 85.7 , 43.3 , and 8.7 gallons ai/acre), respectively) and $380 \mathrm{~mL}(12.8 \mathrm{fl} \mathrm{oz})$ to each young plot $(338,169$, and $34 \mathrm{~L}$ ai/ha, or 36,18 , and 3.6 gallons ai/acre, respectively). Shoot mortality was determined, and damaged leaves on six shoots (young cotton and Palmer amaranth) or 10 shoots (mature Palmer amaranth) per plot were counted $72 \mathrm{hr}$ (young cotton and Palmer amaranth) or one week (mature pigweed) after application.

To examine the influence of weed and cotton age on vinegar efficacy, a field experiment was conducted in July 2006 at the USDA-ARS KSARC Rio Delta Experimental Farm ( $26^{\circ} 26^{\prime} \mathrm{N}, 97^{\circ} 57^{\prime} \mathrm{W}$ ) in fine sandy-loamy soil similar to that of the January 2006 hairy vetch vinegar experiment. Plots $\left(1 \mathrm{~m}^{2}\right)$ were fertilized with $40 \mathrm{~g}(1.4 \mathrm{oz})$ Osmocote $^{\circledR}$ (Scotts-Sierra, Marysville, OH) (15-9-12 N-P-K plus micronutrients). Seeds of Palmer amaranth $\left(1.0 \mathrm{~g} / \mathrm{m}^{2}\right)$, purslane $\left(0.7 \mathrm{~g} / \mathrm{m}^{2}\right)$, and cotton (10 seeds) (Fibermax 960RR) were hand-sown into plots. Sunflower and additional cotton seedlings were grown until they had cotyledons plus one true leaf in a greenhouse and then transplanted to field plots (15 plants per plot). A total of 20 plots of each plant species were established. Shoot height (or breadth of prostrate stems in purslane) and number of leaves were determined for five plants in each control plot at each application time, 10, 16, 23, and 30 days after emergence. Plots (four per plant species per vinegar treatment per application time) received $9 \%$ vinegar and surfactant solution at a rate of $300 \mathrm{~mL} /$ plot $(2,980 \mathrm{~L} / \mathrm{ha}$ or 319 gallons/acre solution) containing $266 \mathrm{~L}$ ai/ha (28.4 gallons ai/acre). Separate groups of four plots per plant species were sprayed with the surfactant-only control solution. Mortality was assessed $1 \mathrm{wk}$ after application.

The effects of vinegar on arcsine-square root-transformed percent mortality of weeds and cotton were examined using PROC NPAR1WAY 
(SAS Institute, 1999) and methods similar to those used to assess changes in live cover crop cover. One-way analysis of variance (ANOVA) using SAS PROC GLM and Tukey mean separation were used to analyze the effects of vinegar dose on proportions of Palmer amaranth and cotton leaves per shoot that were damaged in field plots.

\section{Effect of Vinegar on Soil Surface pH}

One wk after the winter 2006 application of $0 \%, 0.9 \%, 4.5 \%$, and $9 \%$ vinegar to cover crops within the sustainable field, one $20 \mathrm{~g}(0.7 \mathrm{oz})$ sample from the top $1 \mathrm{~cm}(0.4 \mathrm{in})$ of bare soil, free from plant residue, was collected inside each $1 \mathrm{~m}^{2}$ subplot. Soil samples were suspended in $40 \mathrm{~mL}$ ( $1.4 \mathrm{fl} \mathrm{oz}$ ) deionized water, agitated for $15 \mathrm{~min}$ and allowed to settle for $1 \mathrm{hr}$ at $25^{\circ} \mathrm{C}$. The $\mathrm{pH}$ was determined with a Model 300729.1 wet electrode connected to a Model $215 \mathrm{pH}$ meter (Denver Instruments, Denver, $\mathrm{CO})$. Effects on $\mathrm{pH}$ were analyzed with one-way ANOVA.

\section{RESULTS AND DISCUSSION}

\section{Cover Crops and Winter Weeds}

Common purslane was the most common winter weed ( $88 \%$ of 117 subplots sampled in 2005 and 2006) and was equally likely to be present in all three cover crop treatments. Palmer amaranth occurred in 54\% of all subplots, but was found more often in subplots containing hairy vetch $(67 \%)$ or no cover $(59 \%)$ than in black oat subplots $(36 \%)\left(\chi^{2}=8.1\right.$, p < 0.05), as was wild lettuce, Lactuca ludoviciana (Nutt.) Ridd) which occurred in $42 \%$ of all winter 2006 subplots $(75 \%$ in $\mathrm{HV}, 38 \%$ in $\mathrm{NC}$, $13 \%$ in BO; $\left.\chi^{2}=21, p<0.001\right)$. Grasses occurred in $39 \%$ of 2006 samples and were less common (4\%) in BO subplots than in $\mathrm{HV}(50 \%)$ and $\mathrm{NC}$ subplots $(63 \%)\left(\chi^{2}=23, \mathrm{p}<0.001\right)$. Other winter weeds encountered in winter 2006 sampling were rocket mustard, Sisymbrium irio L. (15\%), henbit, Lamium amplexicaule L. (6\%), common sunflower, Helianthus annuus L. (4\%), purple sedge, Cyperus rotundus L. (3\%), camphor weed, Heterotheca latifolia Buckl. $(<1 \%)$ and cowpen daisy, Verbesina encelioides (Cav.) Gray (< 1\%). Volunteer cotton and alfalfa were also observed (11\% and $4 \%$, respectively). BO and $\mathrm{HV}$ plots had $61 \%$ and $52 \%$ more total plant cover than did NC plots, respectively (Table 1). BO plots had 8 and $17 \%$ less total weed cover, respectively, than did $\mathrm{NC}$ and $\mathrm{HV}$ plots, and purslane coverage was $5 \%$ lower in $\mathrm{BO}$ plots than in $\mathrm{HV}$ 
and NC plots, while Palmer amaranth cover did not vary among cover treatments (Table 1). In winter 2005 samples, common purslane seedling density was 3.6-fold higher in BO plots (mean $\pm \mathrm{SE} ; 30 \pm 9$ shoots $/ \mathrm{m}^{2}$ ) and 2.5-fold higher in HV plots $\left(21 \pm 6\right.$ shoots $\left./ \mathrm{m}^{2}\right)$ than in NC plots $(8.3 \pm 3$ shoots $\left./ \mathrm{m}^{2}\right)(\mathrm{F}=25.9, \mathrm{df}=2,4, \mathrm{p}<0.01)$, while Palmer amaranth shoot density did not vary significantly among cover crops (BO, $1.9 \pm 0.8 ; \mathrm{HV}$, $3.5 \pm 1.2 ; \mathrm{NC}, 0.4 \pm 0.2$ shoots $/ \mathrm{m}^{2}, \mathrm{p}=0.249$ ).

The results concur with past findings that winter cover crops vary in their weed suppressive abilities. Grasses such as black oats can suppress weeds to a greater extent than legumes like hairy vetch (Yenish et al., 1996). In this study, black oats suppressed total weed and purslane cover more than either hairy vetch or tillage without cover cropping. Several factors may have promoted greater weed suppression by black oats, including the two fold higher seeding rate and the higher coverage attained by this crop (Table 1) (Hoffman and Regnier, 2006) compared to hairy vetch, even though hairy vetch inhibited weed seed germination and seedling establishment through both chemical allelopathy (Bauer and Reeves, 1999; Kamo et al., 2003, Nava-Rodriguez et al., 2005; Teasdale and Pillai, 2005) and physical obstruction of space and light. Physical factors may have been more important in this experiment. Non-living materials like plastic and non-allelopathic plant residues can physically suppress

TABLE 1. Percent total plant, cover crop, total winter weed, Palmer amaranth, and purslane cover as influenced by winter cover crops in 2005 and 2006, in a field being prepared for sustainable cotton cultivation. ${ }^{\text {a }}$

\begin{tabular}{lccccc}
\hline Cover Crop $^{\mathrm{b}}$ & Total & Cover crop & Total weed & Palmer amaranth & Purslane \\
\cline { 2 - 6 } & \multicolumn{5}{c}{$\%$ cover } \\
\hline BO & $78.7 \pm 1.7^{\mathrm{a}}$ & $69.8 \pm 2.2^{\mathrm{a}}$ & $8.9 \pm 1.5^{\mathrm{b}}$ & $1.6 \pm 0.5^{\mathrm{a}}$ & $5.9 \pm 1.4^{\mathrm{b}}$ \\
HV & $68.9 \pm 2.5^{\mathrm{a}}$ & $43.2 \pm 2.8^{\mathrm{b}}$ & $25.7 \pm 1.7^{\mathrm{a}}$ & $8.3 \pm 1.4^{\mathrm{a}}$ & $11.3 \pm 1.7^{\mathrm{a}}$ \\
NC & $17.3 \pm 2.0^{\mathrm{b}}$ & $0^{\mathrm{c}}$ & $17.3 \pm 2.0^{\mathrm{a}}$ & $3.9 \pm 0.8^{\mathrm{a}}$ & $10.4 \pm 1.4^{\mathrm{a}}$ \\
F, $\mathrm{p}^{\mathrm{c}}$ & $456.6,<0.001$ & $402.8,<0.001$ & $24.3,<0.01$ & $2.4,>0.05$ & $12.0,<0.05$ \\
\hline
\end{tabular}

aValues (mean \pm SE) represent the average of $391 \mathrm{~m}^{2}$ subplots sampled in 2005 and 2006 for each treatment.

${ }^{\mathrm{b}}$ Abbreviations: $\mathrm{BO}$, black oats; HV, hairy vetch; NC, no cover.

${ }^{\mathrm{C}} \mathrm{F}$ and $\mathrm{p}$ values reflect the effect of cover crop in analyses of variance (df $=2,4$ ). Differing letters within columns denote significant differences among cover crops in Tukey-Kramer tests $(p<0.05)$. 
redroot pigweed (Amaranthus retroflexus L.) and other weeds (Hill et al., 2006; Teasdale and Mohler, 2000). The higher numbers of purslane seedlings in $\mathrm{BO}$ and $\mathrm{HV}$ plots are suggestive of a transient physical benefit of cover, such as increased moisture retention under drought conditions (Teasdale and Mohler, 2000), which were present throughout winter and spring sampling in 2005 and 2006. Alternatively, stimulation by low concentrations of exudates or nutritive leachates (Hill et al., 2006; Teasdale and Pillai, 2005), promoted seed germination and seedling establishment, but not shoot growth. The reduced occurrence of Palmer amaranth, wild lettuce, and grasses in BO plots illustrate the ability of cover crops to alter the composition of weed communities (Barberi and Mazzoncini, 2001).

\section{Cover Crops and Spring Weeds}

Seven WAP, purslane was the most common weed (58\% of 114 total subplots in the sustainable field sampled in 2005 and 2006), and occurrence did not vary according to winter cover. Palmer amaranth was found in $52 \%$ of all subplots, and, as in winter samples, was more likely to occur in $\mathrm{HV}(72 \%)$ than in BO $(42 \%)$ or $\mathrm{NC}(41 \%)$ subplots $\left(\chi^{2}=9.8, \mathrm{p}<0.01\right)$. At least one type of grass occurred in $46 \%$ of all 2006 subplots. Johnsongrass (Sorghum halapense (L.) Pers) occurred in $23 \%$ of subplots, but was found more frequently in BO $(28 \%)$ and $\mathrm{HV}(36 \%)$ than in NC $(5 \%)$ subplots $\left(\chi^{2}=13, \mathrm{p}<0.005\right)$, possibly reflecting an increased susceptibility of johnsongrass to winter tillage and spring cultivation in NC plots, because of its tendency to grow in inter-row spaces (S. Greenberg, personal observation). At least one composite (Family Asteraceae) was found in $24 \%$ of samples, with no differences between winter covers. Sunflower was the most common species in this group (21\%), with other species (sow thistle, Sonchus oleraceus L. and cowpen daisy) occurring in less than $1 \%$ of subplots. Other weeds observed in $5 \%$ or less of subplots included purple nutgrass (Cyperus rotundus L.), goosefoot (Chenopodium murale L. and C. berlanderi Moq.), croton (Croton leucophyllus Muell. Arg.), spurge (Euphorbia spp.), powderpuff (Mimosa strigillosa T. and G.), American nightshade (Solanum americanum Mill.), netted globe berry (Margaranthus solanaceus Schlecht), and rocket mustard. Volunteer hairy vetch, black oats, alfalfa, and beets (Beta vulgaris L.) were also observed.

Seven WAP (3 weeks after sweep cultivation), total plant, total weed, Palmer amaranth and purslane cover did not differ according to winter cover within the sustainable cotton field (Table 2), nor did the density of 
TABLE 2. Percent total plant, cotton, total spring weed, Palmer amaranth, and purslane cover as influenced by prior-tilled winter cover crops in sustainable cotton cultivation in $2006^{\mathrm{a}}$

\begin{tabular}{lccccr}
\hline Cover Crop & Total & Cotton & Total weed & Palmer amaranth & Purslane \\
\cline { 2 - 6 } & \multicolumn{5}{c}{$\%$ cover } \\
\hline BO & $44.7 \pm 2.1^{\mathrm{a}}$ & $26.7 \pm 2.6^{\mathrm{a}}$ & $18.0 \pm 2.2^{\mathrm{a}}$ & $2.8 \pm 1.0^{\mathrm{a}}$ & $12.4 \pm 1.7^{\mathrm{a}}$ \\
$\mathrm{HV}$ & $42.7 \pm 3.6^{\mathrm{a}}$ & $14.0 \pm 1.5^{\mathrm{b}}$ & $28.7 \pm 4.0^{\mathrm{a}}$ & $15.9 \pm 4.6^{\mathrm{a}}$ & $8.5 \pm 3.0^{\mathrm{a}}$ \\
NC & $41.3 \pm 3.0^{\mathrm{a}}$ & $20.8 \pm 1.9^{\mathrm{b}}$ & $20.5 \pm 3.4^{\mathrm{a}}$ & $12.0 \pm 3.8^{\mathrm{a}}$ & $8.0 \pm 2.2^{\mathrm{a}}$ \\
F, $\mathrm{p}^{\mathrm{c}}$ & $0.3,>0.05$ & $9.8,<0.05$ & $2.6,>0.05$ & $2.5,>0.05$ & $2.0,>0.05$ \\
\hline
\end{tabular}

aValues (mean $\pm \mathrm{SE}$ ) represent the average of $151 \mathrm{~m}^{2}$ subplots per cover crop treatment.

${ }^{\mathrm{b}}$ Abbreviations: $\mathrm{BO}$, black oats; $\mathrm{HV}$, hairy vetch; $\mathrm{NC}$, no-cover.

${ }^{\mathrm{C}} \mathrm{F}$ and $\mathrm{p}$ values reflect the effect of cover crop in analyses of variance $(\mathrm{df}=2,4)$. Differing letters denote significant differences among plots in Tukey-Kramer tests $(p<0.05)$.

Palmer amaranth shoots, which varied greatly among subplots (mean \pm SE; $\mathrm{BO}, 1 \pm 0.5 ; \mathrm{HV}, 160 \pm 40 ; \mathrm{NC}, 77 \pm 31$ shoots $\left./ \mathrm{m}^{2}\right)(\mathrm{p}=0.189)$. However, more of the total plant cover consisted of weeds in former HV plots $(64 \pm 5 \%)$, than in former BO $(41 \pm 5 \%)$ or $\mathrm{NC}$ plots $(46 \pm 6 \%)$ $(\mathrm{F}=5.3 ; \mathrm{df}=2,4 ; \mathrm{p}=0.07)$. Cotton occupied $13 \%$ and $6 \%$ more cover in BO plots than in $\mathrm{HV}$ and $\mathrm{NC}$ plots, respectively (Table 2). Cotton height, however, did not vary according to past winter cover $(\mathrm{BO}, 27.1 \pm 2.0 \mathrm{~cm}$; $\mathrm{HV}, 21.3 \pm 2.1 \mathrm{~cm}$; NC, $19.4 \pm 2.2 \mathrm{~cm})(\mathrm{p}=0.295)$. By comparison, weed cover in conventional plots was $3.7 \pm 1.0 \%$, cotton cover was $31.1 \pm 1.5 \%$, and cotton heights were $23.1 \pm 1 \mathrm{~cm}$.

Cover crop residues on the soil surface can reduce weed establishment and growth (Bauer and Reeves, 1999, Fisk et al., 2001; Teasdale and Rosecrance, 2003), but this study examined the effects of soil-incorporated cover residues. The beneficial effects of black oats on the soil (Bauer and Reeves, 1999) and modestly reduced Palmer amaranth seedling occurrence, cover and density in former BO plots, may have allowed cotton in former $\mathrm{BO}$ plots to develop and expand leaves more rapidly than did cotton in former $\mathrm{HV}$ and NC plots, without influencing seedling height. In tests in the state of Georgia, black oats enhanced early-season cotton height more than did hairy vetch or five other cover crops (Schomberg et al., 2006). Hairy vetch can enhance cotton height either with or without residue incorporation (Boquet et al., 2004), but hairy vetch plots in this study had higher winter weed cover than black oats plots and possibly enhanced 
weed seed production. Cultivation can stimulate weed seed germination (Mohler, 2001a), and in HV plots, residue incorporation and subsequent interrow cultivation may have reduced the potential benefits of prior vetch cover for crop growth. The efficacy of spring weed suppression by incorporated cover residues did not vary greatly between winter cover species, in contrast to the variable efficacy of surface cover residues (Burgos et al., 2006; Hoffman and Regnier, 2006; Teasdale and Mohler, 2000).

Subplots from which cultivation was withheld for 4 weeks had $50 \%$ more total plant cover $(\mathrm{p}=0.009)$ and $55 \%$ more total weed cover $(\mathrm{p}=0.004)$ than cultivated areas across winter cover treatments (Figure 1A), and within treatments $(\mathrm{BO}, \mathrm{p}=0.059 ; \mathrm{HV}, \mathrm{P}=0.014 ; \mathrm{NC}, \mathrm{p}=0.012)$. Total spring weed cover was roughly similar in reduced-cultivation strips within all sustainable treatments (BO, $75 \pm 4 \%$; HV, $84 \pm 3 \%$; NC, $74 \pm 3 \%$ ). Palmer amaranth, purslane and cotton cover (Figure 1A), Palmer amaranth shoot density (cultivated, $77 \pm 19$ shoots $/ \mathrm{m}^{2}$; not cultivated, $40.0 \pm 10$ shoots $/ \mathrm{m}^{2} ; \mathrm{p}=0.460$ ), and 7-week-old cotton height (cultivated, $22.6 \pm 1.3$; not cultivated, $21.6 \pm 1.9$ ) were not affected by withholding cultivation ( $p>0.05$ ). Adverse effects on young cotton may have been ameliorated by abundant soil resources (Mohler, 2001a), but full-season cotton growth and yield would have likely been affected, either with (Griffith et al., 2006) or without (Rowland et al., 1999) mechanical weed removal.

FIGURE 1. Percent total (TC), crop (cotton [CO] in Figure 1A; alfalfa [AL] in Figure 1B), total weed (WC), Palmer amaranth (PA), and purslane (PU) cover in early-season sustainable cotton production. A. Cover in cultivated plots of all three winter cover treatments (average \pm SE of $451 \mathrm{~m}^{2}$ subplots) and in strips left uncultivated for 4 wk (average \pm SE of 24 subplots). B. Cover in alfalfa strips in 2005 (mean \pm SE of 30 subplots) and 2006 (mean \pm SE of 18 subplots). Bars with different letters vary significantly (Tukey-Kramer tests, $\mathrm{p}<0.05$ ) in cover between cultivation treatment $(\mathbf{A})$ or year (B).
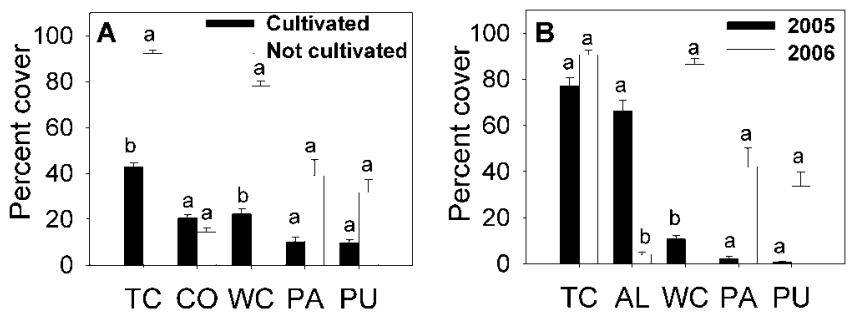
Failure of the alfalfa strips in 2006 led to $75 \%$ higher total weed cover in these strips than in 2005 (Figure 1B) $(\mathrm{p}=0.006)$, with similar trends for Palmer amaranth $(\mathrm{P}=0.081)$ and purslane $(\mathrm{P}=0.094)$, which occurred in $94 \%$ and $100 \%$ of alfalfa subplots in 2006, respectively, compared to $30 \%$ and $13 \%$ in $2005\left(\chi^{2}=22\right.$ and $\chi^{2}=43$, respectively, $\left.\mathrm{p}<0.001\right)$. The results show that two years of hairy vetch and black oat covers were not sufficient to obviate the need for cultivation and alfalfa strips as spring weed management strategies.

\section{Sustainable Production and Yield}

The use of winter cover crops and avoidance of herbicides incurred a penalty in increased spring weed cover relative to conventional weed control, and slightly influenced early-season cotton size. However, cotton yields were similar in sustainable and conventional plots, in both 2005 (mean $\pm \mathrm{SE}$; sustainable, $1,065 \pm 60 \mathrm{~kg} / \mathrm{ha}$ or $1.98 \pm 0.11$ bales/acre; conventional $1,232 \pm 72 \mathrm{~kg} / \mathrm{ha}$ or $2.29 \pm 0.14$ bales/acre; $\mathrm{t}=0.72, \mathrm{df}=19$, $\mathrm{p}=0.510$ ) and 2006 (sustainable, $580 \pm 68 \mathrm{~kg} / \mathrm{ha}$ or $1.08 \pm 0.13$ bales/ acre; conventional $665 \pm 95 \mathrm{~kg} / \mathrm{ha}$ or $1.24 \pm 0.18$ bales/acre; $\mathrm{t}=1.8, \mathrm{df}=5$, $\mathrm{p}=0.094)$. The results suggest that weed control with winter cover cropping and spring cultivation, augmented with hand-weeding in the first 8 WAP, generated yields similar to conventional production, when used in concert with sustainable insect pest and fertilization techniques and conventional height control and defoliation techniques. Past studies have shown economically viable cotton yields in systems involving hairy vetch cover despite increased weed densities (Boquet et al., 2004).

\section{Vinegar for Cover Crop Control}

In two experiments, application of full-strength (9\% acid) vinegar solution was necessary to consistently lower live hairy vetch and black oat winter coverage below levels associated with the control solution (Figure 2). Final live vetch cover in $1 \mathrm{~m}^{2}$ plots one week after treatment was $4 \pm 1 \%$, in the first experiment and $50 \pm 2 \%$ in the second experiment, suggesting variation in either environmental conditions or cover crop phenology. Vetch is easier to kill with synthetic herbicides in the mid- to late-flowering stage than in the early flower bud stage (Hoffman and Regnier, 2006), and hairy vetch was 1 to 2 weeks older in the more successful vinegar trial. In contrast to some past data (Burgos et al., 2006), vinegar was less effective in reducing live black oats cover than hairy vetch cover (Figure 2), with $57 \pm 8 \%$ live black oats still remaining. One application of $9 \%$ vinegar did not 
FIGURE 2. Change in estimated coverage of hairy vetch (HV) or black oats (BO) in $1 \mathrm{~m}^{2}$ plots 1 week after application of $0 \%, 0.9 \%, 4.5 \%$, or $9.0 \%$ vinegar solution in two trials (E1, E2). Bars represent the mean \pm SE of six plots per cover crop per experiment. Asterisks $(*)$ indicate changes in cover that are significantly different (Wilcoxon $\chi^{2}$ tests, $\left.p<0.05\right)$ from the change caused by control solution.

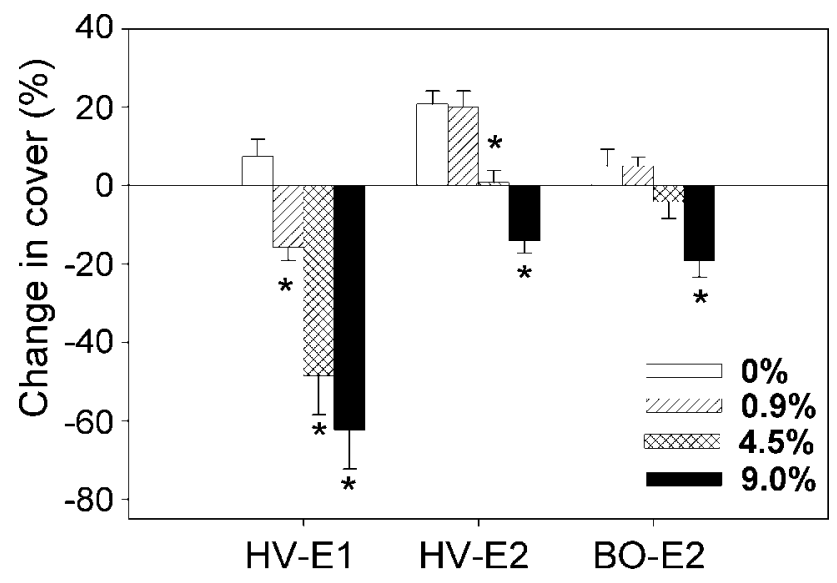

significantly alter soil surface $\mathrm{pH}(\mathrm{p}=0.473)$ (control solution, $7.63 \pm 0.07$; $9.0 \%$ vinegar, $7.47 \pm 0.03$ ). The use of acetic acid does not inhibit soil microbiological activities and may generate additional organic carbon (Malkomes, 2006). However, the overall level of cover crop kill provided by vinegar was inferior to that of glyphosate at 1 to $3 \mathrm{~kg} / \mathrm{ha}$ (0.9 to $2.7 \mathrm{lbs} / \mathrm{acre}$ ) (Hoffman and Regnier, 2006). Similarly, repeated applications of 5\% to $7 \%$ acid vinegar provided only $60 \%$ to $80 \%$ control of hairy vetch (Young, 2004). At least 95\% kill is needed in no-till systems, which, although not used in this study, are common in both sustainable and conventional crop production. Repeated application or the use of vinegar concentrations higher than $9 \%$ acid may have increased cover crop mortality, but the amount or concentration of vinegar required may have been impractical.

\section{Vinegar for Weed Control in Cotton}

Because of its potential as a non-selective contact herbicide (Webber et al., 2005; Young, 2004), vinegar was evaluated as an alternative to synthetic herbicides, cultivation and hand-weeding. Past work (Showler and Greenberg, 2003) and this study found that Palmer amaranth, common 
purslane, and composites such as sunflower are the most common winter and early spring broadleaf weeds in cotton fields in the LRGV of Texas. In $1 \mathrm{~m}^{2}$ winter plots containing purslane, only $17 \pm 6 \%$ of shoots were killed by $9 \%$ vinegar, compared to $12 \pm 5 \%$ in plots that received surfactant only $(\mathrm{p}=0.629)$. In winter applications to individual plants, vinegar was ineffective in killing individual Palmer amaranth and sunflower shoots ( 0 and $10 \%$ mortality, respectively). In similar spring tests, $38 \%$ of Palmer amaranth, $19 \%$ of purslane, and $67 \%$ of sunflower plants were killed when sprayed with $9.0 \%$ vinegar. Warmer spring temperatures may have enhanced vinegar efficacy, consistent with recommendations to apply under full sunlight (Garrett, 1999), but even these mortality levels do not compare favorably with those associated with synthetic contact herbicides (Heap, 2005).

In August 2005 tests, young volunteer cotton and Palmer amaranth in $1 \mathrm{~m}^{2}$ plots in fallow areas showed near-equal levels of mortality $(28 \%$ and $26 \%$, respectively) in response to $9 \%$ vinegar, significantly greater than the response to surfactant only (cotton, $\chi^{2}=11.7, \mathrm{p}=0.008$; Palmer amaranth, $\chi^{2}=10.1, p=0.02$ ) (Figure 3A). Lower vinegar doses did not cause mortality greater than the control. Mature, flowering Palmer amaranth shoots were not killed by vinegar (Figure 3A). The 9\% vinegar application damaged $86 \%$ of the leaves on small cotton seedlings $(F=23.3, \mathrm{df}=3$, $16, \mathrm{p}<0.001), 73 \%$ of leaves on small Palmer amaranth plants $(F=40.2$ $\mathrm{df}=3,16, \mathrm{p}<0.001)$ and $45 \%$ of leaves on large, reproductive pigweed plants $(F=6.7$, df $=3,16, \mathrm{P}=0.004)$ (Figure $3 \mathrm{~B})$. Because of leaf

FIGURE 3. Percent mortality (A) and leaf damage (B) after application of $0 \%, 0.9 \%, 4.5 \%$, or $9.0 \%$ vinegar solution to young cotton (YC) and young (YPA) and mature (MPA) Palmer amaranth. Each bar represents the mean \pm SE of five $1 \mathrm{~m}^{2}$ plots. Asterisks in Figure $3 \mathrm{~A}$ indicate mortality levels significantly higher than the control application (Wilcoxon $\chi^{2}$ tests, $p<0.05$ ). Bars with different letters in Figure 3B are significantly different from each other (Tukey tests, $p<0.05$ ).
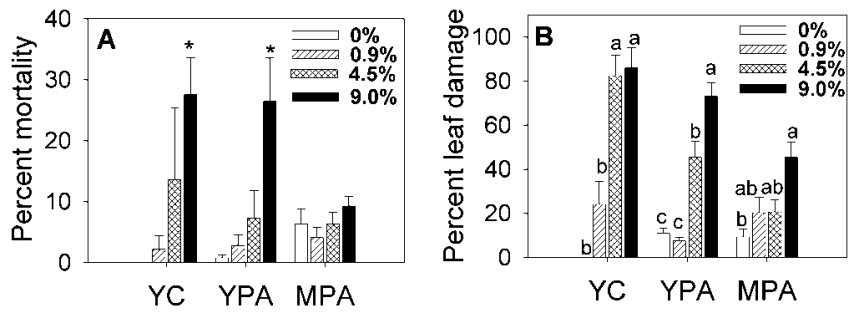
damage, it is possible that Palmer amaranth mortality would have increased after a waiting period longer than 1 week, but this delay would likely be impractical for sustainable weed control.

The trials on volunteer field weeds supported past findings that it is difficult to achieve mortality on mature weeds using vinegar, in part because of insufficient vinegar contact (Young, 2004). The fallow cotton field results suggest that vinegar efficacy varied with weed age, as did our own prior greenhouse results (Moran and Greenberg, 2006), in which 4.5\% or 9.0\% vinegar killed $100 \%$ of 1.5 week-old Palmer amaranth, purslane, and sunflower, while $9.0 \%$ vinegar killed only $12 \%$ to $68 \%$ of 3.5 and 5.5-week-old Palmer amaranth and purslane, and $28 \%$ to $90 \%$ of sunflower. Young (1.5-week-old) cotton plants sprayed with $0.9 \%$ vinegar survived and replaced damaged leaves within two weeks, wile plants exposed to higher concentrations died (Moran and Greenberg, 2006). Most 3.5 and 5.5-week-old cotton (90-100\%) survived application of $9.0 \%$ vinegar, but failed to replace damaged leaves.

In a 2006 field experiment to examine the effects of weed age on vinegar efficacy, full-strength (9\% acid) solution was used because this dose was the only one capable of causing mortality in prior field trials. Fieldsown cotton seedlings sprayed 10 days after emergence were etiolated at the time of application, explaining why they were taller than greenhousegrown and transplanted seedlings sprayed 16 and 23 days after emergence (Table 3). Variation in vinegar-induced mortality according to plant age followed two trends. Cotton and sunflower sprayed any time within the first month after emergence showed $84 \%$ or greater mortality, with the exception of 16-day-old cotton (Table 3). Satisfactory ( $\geq 95 \%$ ) Palmer amaranth and purslane mortality occurred only in plants that were 10 days old (Table 3). Re-application of vinegar to 16-and 23-day-old Palmer amaranth and purslane increased mortality by only $10 \%$ and $0 \%$, respectively, after an additional week.

As with some synthetic herbicides (Sellers et al., 2003; Griffith et al., 2006), and physical control methods like electrocution (Mohler, 2001b), the efficacy of vinegar declined sharply with age in the two most common early-season cotton weeds in the LRGV, Palmer amaranth and purslane. In contrast, sunflower and the cotton crop remained susceptible throughout the first month of field growth. Leaf contact times may be greater on pubescent cotton and sunflower leaves than on smooth, waxy Palmer amaranth and purslane leaves. Declines in efficacy with increasing plant age could be related to lignin accumulation and cell wall strengthening (Boerjan et al., 2003), since the acid likely exerts its effects by rupturing cell walls and 
TABLE 3. Height and number of leaves in field cotton, Palmer amaranth, purslane, and sunflower seedlings $10,16,23$, and 30 days after emergence, and mortality after vinegar application. ${ }^{* \dagger}$

\begin{tabular}{llcccc}
\hline Age & Measure & Cotton & Palmer amaranth & Purslane & Sunflower \\
\hline \multirow{2}{*}{10 days } & Height $(\mathrm{cm})$ & $8.0 \pm 0.6$ & $6.4 \pm 0.3$ & $2.8 \pm 0.4$ & ND \\
& Leaves & $0.2 \pm 0.1$ & $7.8 \pm 0.9$ & $11.7 \pm 3.7$ & ND \\
& Mortality (\%) & $90 \pm 6^{\ddagger}$ & $96 \pm 2^{\ddagger}$ & $98 \pm 2^{\ddagger}$ & ND \\
16 days & Height $(\mathrm{cm})$ & $4.2 \pm 1.0$ & $14.9 \pm 1.2$ & $24.1 \pm 5.4$ & $6.3 \pm 0.3$ \\
& Leaves & $2.0 \pm 0.0$ & $27.1 \pm 2.5$ & $70.0 \pm 17.5$ & $4.0 \pm 0.1$ \\
& Mortality (\%) & $59 \pm 11^{\ddagger}$ & $62 \pm 8^{\ddagger}$ & $26 \pm 3^{\ddagger}$ & $100 \pm 0^{\ddagger}$ \\
23 days & Height $(\mathrm{cm})$ & $7.2 \pm 0.3$ & $51.7 \pm 3.9$ & $50.1 \pm 5.5$ & $8.7 \pm 0.7$ \\
& Leaves & $4.3 \pm 0.1$ & $36.1 \pm 2.8$ & $170 \pm 38.6$ & $8.7 \pm 0.4$ \\
& Mortality (\%) & $98 \pm 2^{\ddagger}$ & $9 \pm 7$ & $7 \pm 7$ & $100 \pm 0^{\ddagger}$ \\
30 days & Height $(\mathrm{cm})$ & $10.9 \pm 0.5$ & $86.6 \pm 10.5$ & $61.1 \pm 2.2$ & $11.4 \pm 1.0$ \\
& Leaves & $6.5 \pm 0.3$ & $27.8 \pm 2.4$ & $239 \pm 38.8$ & $12.0 \pm 0.5$ \\
& Mortality (\%) & $84 \pm 7^{\ddagger}$ & $49 \pm 5^{\ddagger}$ & $6 \pm 6$ & $100 \pm 0^{\ddagger}$ \\
\hline
\end{tabular}

*Each number represents the mean \pm SE of four $1 \mathrm{~m}^{2}$ plots. Mortality was measured one week after application of $9 \%$ vinegar or control solution (2,980 L/ha volume, $266 \mathrm{~L}$ ai/ha). Mortality means within a column and plant age followed by a double dagger fare significantly higher than the mortality associated with control solution $(0 \%$ acid) (Wilcoxon $\chi^{2}$ tests, $p<0.05$ ). ND, not determined.

${ }^{\dagger}$ Control mortality was $1 \%$ to $6 \%$ in cotton, $1 \%$ to $31 \%$ in Palmer amaranth, $0 \%$ to $13 \%$ in purslane, and $0 \%$ to $6 \%$ in sunflower.

membranes. Wind-induced lignin deposition (Cipollini, 1997) could also increase the resistance of field weed seedlings as they age.

\section{CONCLUSIONS}

Black oats and hairy vetch winter cover crops suppressed winter weeds to the same extent or more than did winter tillage in no-cover plots, although black oats favored initial establishment of purslane, and hairy vetch tended to have the same effect on Palmer amaranth, composites and grasses. In the spring, soil-incorporated black oats cover was slightly more beneficial to cotton than incorporated hairy vetch, but neither cover controlled spring weeds. Two years of winter cover cropping did not obviate the need for cultivation, alfalfa strips, and hand-weeding for sustainable spring weed management in cotton in the LRGV of Texas. Among seven cover crops tested in Georgia, U.S.A., black oats in 
combination with strip tillage and limited herbicide use at planting maximized cotton yield and economic returns (Schomberg et al., 2006). The sustainable weed control system used in this study did not negatively affect cotton yield. The benefits of winter cover crops to production crops may be enhanced by residue incorporation (Sainju et al., 2005). Untilled cover residues may be more effective in suppressing Palmer amaranth, purslane, and other weeds after crop planting, and can enhance crop growth (Bauer and Reeves, 1999; Boquet et al., 2004; Fisk et al., 2001; Hoffman and Regnier, 2006; Nagabhushana et al., 2001) but involve some risk to crop establishment (Boquet et al., 2004), and herbicide treatments after crop emergence are often still necessary (Teasdale et al., 2005; Teasdale and Rosecrance, 2003). Further studies are needed to examine interactions between winter cover crops and the wide range of physical, chemical, and biological techniques available (Mohler, 2001b) for weed suppression and promotion of cotton growth. Many studies on herbicide efficacy, cover crop growth and weed suppression, and effects of weeds on crops measure cover, crop or weed biomass as key measures of impact (Hoffman et al., 1996; Koger and Reddy, 2005; Rowland et al., 1999; Teasdale et al., 2005). In this study, visual cover estimates were used rather than biomass, but treatment effects were still discernable.

Vinegar has limited potential as an additional component in sustainable weed control in cotton. The risk of mortality or injury to cotton is high at the dose required for consistent impact on field weeds (at least 9\% acid content), restricting the use of vinegar to non-crop areas. Applications of $9 \%$ vinegar to 10-day-old or younger weeds under conditions of full sun and calm winds could be used to augment tillage before planting and inter-row cultivation after planting. Spot applications to 1 month-old or less volunteer cotton and sunflower should also be effective. Vinegar containing $9 \%$ acid is not effective for killing hairy vetch or black oats and associated weed infestations, or for control of mature Palmer amaranth and purslane. Reports of successful weed control with vinegar in nurseries, home gardens and fields involved acetic acid levels as high as $20 \%$ (Garrett and Beck 1999, Webber et al., 2005). For field crop production, both vinegar concentrations and application rates must be feasible for producers, and some of the rates used in this study likely exceed what is practical. At sub-lethal levels, vinegar could be used to cause leaf damage in weeds outside of crop rows, which could reduce seed production and mitigate herbicide resistance development, a documented problem for Palmer amaranth pigweed (Heap, 2005; Manley et al., 1999), common purlsane (Masabni and Zandstra, 1999), and sunflower (Zelaya and 
Owen, 2004). Many resistance delay techniques involving synthetic chemicals focused on weed reproduction, rather than growth (Beckie and Gill, 2006). The judicious and repeated use of cover crops, tillage, soil cultivation and organic control tools such as vinegar could increase the sustainability of weed control in cotton production in the LRGV of Texas.

\section{REFERENCES}

Barberi, P. and Mazzoncini, M. 2001. Changes in weed community composition as influenced by cover crop and management system in continuous corn. Weed Science 49:491-499.

Batish, D.R., Singh, H.P. Kohli, R.K. and Dawra, G.P. 2006. Potential for allelopathy and allelochemicals for weed management. In H.P. Singh, D.R. Batish, and R.K. Kohli (eds.) Handbook of sustainable weed management. Food Products Press, New York, NY. pp. 209-256.

Bauer, P.J. and Reeves, D.W. 1999. A comparison of winter cereal species and planting dates as residue cover for cotton grown with conservation tillage. Crop Science 39:1824-1830.

Beckie, H.J. and Gill, G.S. 2006. Strategies for managing herbicide-resistant weeds. In H. Pal Singh, D.R. Batish, and R.K. Kohli (eds.) Handbook of sustainable weed management. Food Products Press, New York, NY. pp. 581-625.

Boerjan, W., Ralph, J. and Baucher, M. 2003. Lignin biosynthesis. Annu. Rev. Plant Biol. 54:519-546.

Boquet, D.J., Hutchinson, R.L. and Breitenbeck, G.A. 2004. Long-term tillage, cover crop, and nitrogen rate effects on cotton: plant growth and yield components. Agronomy J. 96:1443-1452.

Burgos, N.R., Taubert, R.E. and Kuk, Y.I. 2006. Grass-legume cover crops for weed management. In H.P. Singh, D.R. Batish, and R.K. Kohli (eds.) Handbook of sustainable weed management. Food Products Press, New York, NY. pp. 95-125.

Carpenter-Boggs, L. 2005. Diving into compost tea. Biocycle 46(7):61-62.

Cipollini, D.F. 1997. Wind-induced mechanical stimulation increases pest resistance in common bean. Oecologia 111:84-90.

Clark, S., K. Szlavecz, Cavigelli, M.A. and Purrington, F. 2006. Ground beetle (Coleoptera: Carabidae) assemblages in organic, no-till, and chisel till cropping systems in Maryland. Environ. Entomol. 35:1304-1312.

DeBach, P. (Ed.), 1964. Biological control of insect pests and weeds. Chapman and Hall, London, $844 \mathrm{pp}$.

Elllington, J., Carrillo, T. and Drake, J. 2003. Pecan integrated biological control. Southwestern Entomologist (Suppl. 27):45-56.

Fausey, J.C. 2003. Controlling liverwort and moss now and in the future. HortTechnology 13:35-38.

Fisk, J.W., Hesterman, O.B. Shrestha, A. Kells, J.J. Harwood, R.R. Squire, J.M. and Sheaffer, C.C. 2001. Weed suppression by annual legume cover crops in no-tillage crops. Agronomy J. 93:319-325. 
Garrett, J.H. and Beck, C.M. 1999. Texas organic vegetable gardening. Lone Star Books, Lanham, MD. 220 pp.

Griffith, G.M., Barrentine, J. and McClelland, M.R. 2006. Weed competition effects in Roundup Ready Flex cotton (Gossypium hirsutum L.). In Proceedings of the Beltwide Cotton Conferences, January 4-8, 2006, San Antonio, Texas. National Cotton Council, Memphis, TN. pp. 2277-2280.

Guerena, M. and Sullivan, P. 2003. Organic cotton production. Appropriate Technology Transfer for Rural Areas (ATTRA) Report No. IP233, Fayetteville, AR. 24 pp.

Heap, I. 2005. The international survey of herbicide-resistant weeds. Herbicide-Resistant Plant Committee, Weed Science Society of America, Lawrence, KS. http://www. weedscience.com.

Hill, E.C., M. Ngouajio, and Nair, M.G. 2006. Differential response of weeds and vegetable crops to aqueous extracts of hairy vetch and cowpea. HortScience 41:695-700.

Hoffman, M.L. and Regnier, E.E. 2006. Contributions to weed suppression from cover crops. In H.P. Singh, D.R. Batish, and R.K. Kohli (eds.) Handbook of sustainable weed management. Food Products Press, New York, NY. pp. 51-75.

Hoffman, M.L., Westron, L.A. Snyder, J.C. and Regnier, E.E. 1996. Allelopathic influence of germinating seeds and seedlings of cover crops on weed species. Weed Science 44:579-584.

Ingham, E. 2005. Compost tea brewing manual, $5^{\text {th }}$ edition. Soil Foodweb, Inc., Corvallis, OR. 79 pp.

Kamo, T., Hiradate, S. and Fujii, Y. 2003. First isolation of natural cyanamide as a possible allelochemical from hairy vetch Vicia villosa. J. Chemical Ecol. 29:275-283.

Koger, C.H. and Reddy, K.N. 2005. Effects of hairy vetch (Vicia villosa) cover crop and banded herbicides on weeds, grain yield, and economic returns in corn (Zea mays). J. Sustainable Agric. 26:107-124.

Kremer, R.J. 2002. Bioherbicides: potential successful strategies for weed control. In O. Koul and G. Dhaliwal (eds.) Microbial biopesticides. Taylor and Francis, London. pp. 307-323.

Kuepper, G., 2002. Organic farm certification and the national organic program. Appropriate Technology Transfer for Rural Areas (ATTRA) Report No. IP232, Davis, CA. 20 pp.

Labrada, R. 2006. Weed management: a basic component of modern crop production. In H.P. Singh, D.R. Batish, and R.K. Kohli (eds.) Handbook of sustainable weed management. Food Products Press, New York, NY. pp. 21-49.

Liebman, M. 2001. Weed management: a need for ecological approaches. In M. Liebman, C.L. Mohler, and C.P. Staver (eds.) Ecological management of agricultural weeds. Cambridge University Press, New York, NY. pp. 1-39.

Litterick, A.M., Harrier, L. Wallace, P. Watson, C.A. and Wood, M. 2004. The role of uncomposted materials, composts, manures, and compost extracts in reducing pest and disease incidence and severity in sustainable temperate agricultural and horticultural crop production-a review. Critical Rev. Plant Sci. 23:453-479.

Malkomes, H.-P. 2006. Microbiological-ecotoxicological soil investigations of two herbicidal fatty acid preparations used with high dosages in weed control. Zeitschrift Umweltchem Okotox 18:13-20. 
Manley, B.S., Singh, B.K. Shaner, D.L. and Wilson, H.P. 1999. Imidazolinone resistance in smooth pigweed (Amaranthus hybridus) is due to an altered acetolactate synthase. Weed Technology 13:697-705.

Masabni, J.G. and Zandstra, B.H. 1999. Discovery of a common purslane (Portulaca oleracea) biotype resistant to linuron. Weed Technology 13:599-605.

Mohler, C.L. 2001a. Mechanical management of weeds. In M. Liebman, C.L. Mohler, and C.P. Staver (eds.) Ecological management of agricultural weeds. Cambridge University Press, Cambridge, UK. pp. 139-209.

Mohler, C.L. 2001b. Weed life history: identifying vulnerabilities. In M. Liebman, C.L. Mohler, and C.P. Staver (eds.) Ecological management of agricultural weeds. Cambridge University Press, Cambridge, UK. pp. 40-98.

Moran, P.J. and Greenberg, S.M. 2006. Winter cover crops and vinegar as weed control techniques in sustainable cotton production. Pp. 2188-2195. In Proceedings of the 2006 Beltwide Cotton Conferences, January 3-6, 2006, San Antonio, Texas.

Nagabhushana, G.G., Worsham, A.D. and Yenish, J.P. 2001. Allelopathic cover crops to reduce herbicide use in sustainable agricultural systems. Alleopathy J. 8:133-146.

Nava-Rodriguez, V., Hernandez-Bautista, B.E. Cruz-Ortega, R. and Anaya, A.L. 2005. Allelopathic potential of beans (Phaseolus spp.) and other crops. Alleopathy Journal 15:197-210.

Norman, J.W., 2004. Lower Rio Grande Valley cotton blue book. Texas Cooperative Extension Regional Report 500-2004, College Station, TX. 7 pp.

OMRI. 2007. Organic Materials Review Institute (OMRI) Crop Products List. Online at http://www.omri.org/crops_generic.pdf.

Ortiz-Ribbing, L. and Williams, M.M.I. 2006. Potential of Phomopsis amaranthicola and Microsphaeropsis amaranthi as bioherbicides for several weedy Amaranthus species. Crop Prot. 25:39-46.

Ozores-Hampton, M., Obreza, T.A. Stoffella, P.J. and Fitzpatrick, G. 2002. Immature compost suppresses weed growth under greenhouse conditions. Compost Science and Utilization 10:105-113.

Richardson, A. 1995. Plants of the Rio Grande delta. University of Texas, Austin, TX. 332 pp.

Rowland, M.W., Murray, D.S. and Verhalen, L.M. 1999. Full-season Palmer amaranth (Amaranthus palmeri) interference with cotton (Gossypium hirsutum). Weed Science 47:305-309.

Sainju, U.M., Singh, B.P. and Whitehead, W.F. 2005. Tillage, cover crops, and nitrogen fertilization effects on cotton and sorghum root biomass, carbon, and nitrogen. Agronomy J. 97:1279-1290.

SAS Institute. 1999. SAS/STAT User's Guide, Version 8. SAS Institute, Inc., Cary, NC. 3809 pp.

Schomberg, H.H., McDaniel, R.G. Mallard, E. Endale, D.M. Fisher, D.S. and Cabrera, M.L. 2006. Conservation tillage and cover crop influences on cotton production on a southeastern U.S. coastal plain soil. Agron. J. 98:1247-1256.

Sellers, B.A., Smeda, R.J. Johnson, W.G. Kendig, J.A. and Ellersieck, M.R. 2003. Comparative growth of six Amaranthus species in Missouri. Weed Science 51:329-333.

Showler, A.T. and Greenberg, S.M. 2003. Effects of weeds on selected arthropod herbivore and natural enemy populations, and on cotton growth and yield. Environmental Entomology 32:39-50. 
Spencer, D.F., Elmore, C.L. Ksander, G.G. and Roncoroni, J.A. 2003. Influence of dilute acetic acid treatments on American pondweed winter buds in the Nevada Irrigation District, California. J. Aquatic Plant Mgmt 41:65-68.

Teasdale, J.R and Daughtry, C.S.T. 1993. Weed suppression by live and desiccated hairy vetch (Vicia villosa). Weed Science 41:207-212.

Teasdale, J.R. and Mohler, C.L. 2000. The quantitative relationship between weed emergence and the physical properties of mulches. Weed Science 48:385-392.

Teasdale, J.R. and Pillai, P. 2005. Contribution of ammonium to stimulation of smooth pigweed (Amaranthus hybridus L.) germination by extracts of hairy vetch (Vicia villosa Roth) residue. Weed Biology Mgmt 5:19-25.

Teasdale, J.R., Pillai, P. and Collins, R.T. 2005. Synergism between cover crop residue and herbicide activity on emergence and early growth of weeds. Weed Science 53:521-527.

Teasdale, J.R. and Rosecrance, R.C. 2003. Mechanical versus herbicidal strategies for killing a hairy vetch cover crop and controlling weeds in minimum-tillage corn production. American J. Alternative Agric. 18:95-102.

Webber, C.L., Harris, M.A. Sherefler, J.W. Durnova, M. and Christopher, C.A. 2005. Vinegar as an organic burn-down herbicide. Pp. 168-172. In L. Brandenberger (ed) Proceedings of the $24^{\text {th }}$ Annual Oklahoma and Arkansas Horticulture Industries Show, January 14-15, 2005, Fort Smith, Arkansas.

Yenish, J.P., Worhsam, A.D. and York, A.C. 1996. Cover crops for herbicide replacement in no-tillage corn (Zea mays). Weed Technology 10:815-821.

Young, S.L. 2004. Natural product herbicides for control of annual vegetation along roadsides. Weed Technology 18:580-587.

Zelaya, I.A. and Owen, M.D.K. 2004. Evolved resistance to acetolactate synthase-inhibiting herbicides in common sunflower (Helianthis annus), giant ragweed (Ambrosia trifida) and shattercane (Sorghum bicolor) in Iowa. Weed Science 52:538-548.

Zibilske, L.M. and Bradford, J.M. 2003. Tillage effects on phosphorous mineralization and microbial activity. Soil Science 168:677-685. 